\title{
AS ARTICULAÇÕES HISTÓRICO-SOCIAIS DO PENSAMENTO GEOGRÁFICO NA MATERIALIZAÇÃO DA SOCIEDADE: A GEOGRAFIA DO TRABALHO
}

\section{Victor Pereira de Sousa ${ }^{1}$ Marcelo Penna da Silva ${ }^{2}$}

Resumo: Na antiguidade o trabalho era visto como algo penoso, como sacrifício à liberdade. Após renovações nesse pensamento, através das correntes de pensamento geográfico, como também, da ascensão e fases do capitalismo, a humidade passa a ver o trabalho como honra ao homem contemporâneo. Testemunhou-se então, uma nova configuração territorial. Através de metodologia de gabinete, baseado em fundamentação teórica de grandes estudiosos acerca da temática, a Geografia do Trabalho busca analisar, entender e contextualizar concepções dessa perspectiva histórico-social do trabalho em relação à sociedade e a (re)configuração espacial, arcabouço do espaço geográfico e da existência material do homem na superfície terrestre.

Palavras-chave: Revolução Industrial; Configuração territorial; Espaço geográfico.

\footnotetext{
1 Graduando em Geografia, Universidade do Estado do Rio de Janeiro (UERJ), Brasil. E-mail: victordesousa@outlook.com.br.

2 Graduando em Geografia, Universidade do Estado do Rio de Janeiro (UERJ), Brasil. E-mail: celo_penna2@hotmail.com.
} 